\title{
MOBILE RESOURCES AS A MEANS \\ OF FORMING COMMUNICATIVE COMPETENCE \\ OF FUTURE POLICE OFFICERS
}

\section{МОБІЛЬНІ РЕСУРСИ ЯК ЗАСІБ ФОРМУВАННЯ КОМУНІКАТИВНОЇ КОМПЕТЕНТНОСТI МАЙБУТНІХ ОФІЦЕРІВ ПОЛІЦІЇ}

\section{Olga Oleksiuk ${ }^{1}$ \\ Alina Kudlay ${ }^{2}$}

DOI: https://doi.org/10.30525/978-9934-588-15-0-16

Abstract. The complex transformational processes that take place in the current conditions of a globalized and fast-changing world testify to the reformation of the ideological and philosophical paradigm of higher education. Extraordinary dynamism, complexity, unpredictability, informationalism, intercultural interaction as defining features of the modern world make significant changes in all spheres of public life, changing the conceptual position of training specialists of a new type of thinking. The new requirements for a graduate of a higher education institution cause the latter to master a number of competencies, among which the dominant place is communicative. In the context of this article, the relevance of forming the communicative competence of future police officers, which is determined by the peculiarities of professional activity, is considered. After all, first of all, it is a smoke character, in its specificity it requires such personal qualities as: communicativeness, culture of communication, ability to adapt quickly in the work team, readiness to adapt quickly to new conditions, to regulate relationships between people in the process of their interaction, and secondly - Two-way, since future police officers can carry out both law enforcement, administrative and recreational activities.

\footnotetext{
${ }^{1}$ Doctor of Pedagogical Sciences, Professor,

Head of the Department of Musicology and Music Education,

Borys Grinchenko Kuiv University, Ukraine

${ }^{2}$ Postgraduate Student of the Department of Higher Education and Science,

Institute of Higher Education,

National Academy of Educational Sciences of Ukraine, Ukraine
} 
Also, it is worth noting that in the system of professional relations «personperson» the ability to communicate plays an important role. At the epicenter of the professional work of future police officers will be a person, so they should be able to communicate with all categories of people regardless of their gender, age, nationality, profession, family status, social background, etc. It is necessary to be able to take into account the personal qualities of each person. In the professional activities of future police officers, communication will have the character of a special task. Some authors and researchers who study the problem of professional development of employees mark communicative competence as a necessary professional quality. In the course of study at the National Academy of Internal Affairs in the study of the discipline of «Personal safety of employees of the National Police» cadets, future police officers have the opportunity to fully develop the skills of communicative competence through mobile resources. In other words, one form of learning is e-learning. Mobile-based learning technologies underpin the organization of the educational process and open up new perspectives for future police officers. First, it is an opportunity to receive practically oriented education in a timely manner by means of e-learning materials. Secondly, future police officers have the opportunity to study independently through e-courses, «attend» virtual seminars, view lecture materials, and perform test tasks on proposed topics in an online learning environment. Thus, the article concluded that in modern conditions of teaching in universities can not be limited only to traditional forms and methods of teaching, it is necessary to use mobile resources in the educational process. Practice shows that the use of mobile resources in training enhances the quality of the educational process and informative material, develops the cognitive abilities of future police officers and their desire for self-improvement. It is also proven in practice that the use of mobile resources in training not only shapes and develops communicative competence, but also shapes creativity, stimulates intellectual activity.

\section{1. Вступ}

Сучасний етап розвитку освіти характеризується інтенсивним пошуком нового в теорії та практиці, що обумовлюється низкою суперечностей, головне з яких - невідповідність традиційних методів і форм навчання і пошук нових тенденцій розвитку системи освіти, які б відпо- 
відали соціально-економічним умовам розвитку суспільства, що, в свою чергу, призвело до виникнення об'єктивних інноваційних процесів.

Процеси реформування національної системи освіти нашої держави вимагають оновлення й модернізації навчальних технологій і методів навчання. Від сучасного вишу вимагається запровадження вимагається нових підходів до навчання, щоб забезпечувати розвиток комунікативних, творчих і професійних компетенцій та стимулюють потребу майбутнього офіцера поліції у самоосвіті на основі змісту та організації освітнього процесу.

Актуальність дослідження проблеми підготовки майбутніх офіцерів поліції обумовлена потребами попиту фахівців з високим рівнем теоретичних і практичних знань і навичок. Перед викладачами, які готують майбутніх офіцерів поліції постає проблема пошуку нових шляхів для підвищення пізнавального процесу і зацікавленості майбутніх офіцерів поліції до освітнього процесу, зміцнення їхньої позитивної мотивації в навчанні. Це потребує поєднання знань, які вони отримують у вищих навчальних закладах зі сферою майбутньої професійної діяльності. Проте, незаперечним фактом в цьому процесі $\epsilon$ психологія та педагогіка людських стосунків. Доречним це питання постає перед майбутніми офіцерами поліції, діяльність яких пов'язана з безпосереднім контактом з людьми.

Отже, вимоги до освітнього процесу підвищуються, і роль навчального закладу визначається у застосуванні сучасних тенденцій розвитку, зокрема, мобільних ресурсів.

Мета статті - з'ясувати поняття «мобільні ресурси» та висвітлити їхню роль у формуванні комунікативної компетентності майбутніх офіцерів поліції.

\section{2. Аналіз останніх досліджень і публікацій}

Аналіз останніх досліджень і публікацій довів, що вже утворилася значна база робіт, які висвітлюють проблеми навчання за допомогою мобільних ресурсів. Серед науковців, які опікуються цією проблемою, можна назвати В. Бикова, А. Гуржія, М. Жалдака, А. Литвина, Н. Морзе, В. Олійника, О. Співаковського, Ю. Триуса, Гж. Кєдровича, В. Бикова, М. Жалдака, І. Богданової, І. Теплицького, Е. Сарафанюка, О. Кузнєцова, В. Монахова, Е. Полат, І. Роберт тощо. 
Теоретичні й практичні аспекти використання інтерактивних методів навчання відображено у доробках I. Вачкова, Ю. Смельянова, С. Крамаренко, А. Мартинець, Н. Оганесян, Л. Пироженко, О. Пометун, Т. Яценко. Також І. Золотарьовою та А. Труш розглянуто підходи до застосування мобільного навчання в системі освіти. Н. Рашевською та В. Ткачук запропоновано декілька напрямів реалізації мобільного навчання, зокрема для побудови моделі змішаного навчання. Є. Ливською описано досвід впровадження мобільного навчання у вищому навчальному закладі, а саме у процесі навчання іноземної мови. А, отже, не викликає сумніву той факт, що мобільне навчання $€$ «новітньою освітньою парадигмою, на основі якої створюється нове навчальне середовище, де здобувачі вищої освіти можуть отримати доступ до навчальних матеріалів у будь-якій час і в будь-якому місці» $[1$, с. 9]. Проте, аналіз теоретичних досліджень і практичного досвіду засвідчив, що, незважаючи на пильну увагу до підвищення якості освіти у вищих навчальних закладах за допомогою мобільних ресурсів та їхнього використання у формуванні комунікативної компетентності майбутніх офіцерів поліції потребує глибшого вивчення.

\section{3. Сутність поняття «комунікативна компетентність майбутніх офіцерів поліції»}

У контексті нашого дослідження вважаємо доцільним конкретизувати суть понять: «комунікативна компетентність майбутніх офіцерів поліції» та «мобільні ресурси».

Проблема комунікативної компетентності простежується в дослідженнях психологів і психолінгвістів (Б. Ананьєв, М. Бахтін, Л. Божович, П. Гальперін, М. Жинкін, І. Зимня, О. Леонтьєв, О. Лурія, С. Рубінштейн, О. Синиця та ін.), мовознавці (О. Ахманова, Н. Бабич, Л. Булаховський, В. Виноградов, Д. Ганич, Б. Головін, М. Жовтобрюх, В. Костомаров, Л. Мацько, І. Олійник, Л. Скворцов та ін.), дидакти і лінгводидакти (А. Алексюк, О. Біляєв, Є. Голобородько, Г. Дідук, В. Мельничайко, Г. Михайловська, В. Онищук, Е. Палихата, М. Пентилюк, К. Плиско, М. Стельмахович, О. Хорошковська та ін.).

Проблемам мовленнєвої комунікативної підготовки майбутніх офіцерів поліції присвячені праці О. Бандурки, І. Кириченка, В. Лукашевича, В. Синьова, В. Шакуна та ін. Психолого-педагогічні аспекти про- 
фесійної підготовки працівників правоохоронних органів розглядали В. Галузинський, Г. Яворська. Як важливий елемент професійної діяльності працівника поліції досліджувала культуру мовлення В. Клименко. Окремі аспекти фахового мовлення представників цієї категорії розглядали Л. Аніканова, Н. Артикуца, В. Демченко, О. Копиленко, Л. Корж, С. Кравченко, Г. Мурашин, Ю. Прадід, В. Радецька, О. Сербенська, В. Сімонок, Б. Стецюк, А. Тоцька, 3. Тростюк, О. Юрчук та ін. [1, с. 9].

А. Дулов, говорячи про сенс комунікативної діяльності слідчого, вказував головним чином на отримання необхідної інформації в процесі спілкування. Відповідно, затребуваними виявляються знання, вміння, навички іiі здобуття в спілкуванні та використання у професійній діяльності. Цієї самої позиції дотримуються Ю. Чуфаровський, Ю. Антонян, М. Єнікєєв, В. Емінов. В. Носков пов'язує успішність у вирішенні багатьох комунікативних завдань оперативного працівника 3 високим ступенем володіння психотехніками спілкування [5, с. 143].

На думку В.І. Розова нині висуваються нові вимоги до комунікативних якостей майбутніх офіцерів поліції, у першу чергу до професійно важливих. Тобто, комунікативна підготовка, поряд з когнітивною та емоційно-вольовою - важлива складова професійно-психологічної підготовки майбутнього офіцера поліції.

Теоретичні аспекти комунікативної компетентності формуються під впливом прикладних сфер, у межах яких комунікативна дія, інтеракції особистостей відіграють провідну роль: постають складовими соціокультурного процесу, забезпечують можливість формування соціальних зав'язків, керують спільною життедіяльністю людей i регулюють iï окремі сфери, зберігають досвід та передають його наступним поколінням. До того ж в основі розвитку комунікативної компетентності у сфері «людина-людина» знаходиться встановлення успішної взаємодії в різних по змісту і формі ситуаціях професійного спілкування. Акцент у цьому випадку робиться на тому, що майбутній офіцер поліції повинен не лише забезпечити повноцінне спілкування i досягти позитивних змін у діалозі «офіцер поліції - громадянин», але й зберегти своє власне благополуччя. Для того щоб якісно підійти до оцінки стану комунікативної підготовки майбутніх офіцерів поліції, проаналізувати педагогічні умови іï формування, необхідно зрозуміти що «комунікативна компетентність» - це термін, який належить 
до проблеми спілкування і комунікації, поруч з «комунікативністю», «комунікабельністю», «спілкуванням».

Описуючи бачення і цитуючи вчених - філософів, психологів, педагогів, культурологів - доречно згадати відомий тезис про те, що «наука не відкриває істину, вона ії лише уточнює».

Наукове наповнення терміну «комунікативна компетентність» визначається змістом поняття «комунікація». В «Академічному тлумачному словнику української мови» в 11 томах (1970-1980) первинне значення комунікації - це шлях сполучення лінії зв'язку, а друге - те саме що спілкування, зв’язок. У психологічному словнику «комунікація» визначається як суттєвий аспект соціальної взаємодії; будь-яка індивідуальна дія, що реалізується в умовах прямих чи непрямих відносин з іншими людьми та містить не тільки фізичний, а й комунікативний аспект [3 c. 15]. Найбільш глибоке тлумачення даного терміна подано у «Філософському енциклопедичному словнику» [6 с. 268], комунікація (від лат. communicatio - повідомлення, передача) - спілкування, обмін думками, відомостями, ідеями, тощо; передача певного змісту від однієї свідомості (колективної, абр індивідуальної) до іншої через знаки, зафіксовані на матеріальних носіях. Це соціальний процес, що відтворює суспільну структуру і виконує в ній об'єднувальну функцію» [7, с. 15]. Отже, поняття комунікації використовується для визначення загального зв'язку будь-яких об'єктів матеріального і духовного світів [3, с. 15].

Сьогодні існує понад сорока підходів до комунікації, які розглядаються в різних сферах життя людини. Найбільш відомі теорії комунікації: Г. Лассвелла, К. Шеннона і У. Уівера, М. Маклюена, Р. Якобсона, Н. Бора, М. Бахтіна, Р. Барта, Т. Ньюкома, Х. Фестера, У. Матурана, О. Розеншток-Хьюссі.

Сучасну комунікацію у широкому значенні визначають як передавання інформації від «відправника» до «рецепієнта», специфічну форму взаємодії індивідів у процесі їхньої пізнавально-трудової діяльності, а спілкування - як симетричний зв'язок однаково активних суб'єктів (людина-людина). Цю точку зору поділяє і М. Каган, наголошуючи, про те, що спілкування має на меті прилучення суб'єкта до суб'єкта $[19$, с. 213]. Під прогресуючими ступенями такого «прилучення» мається на увазі толерантність, повага, співчуття, співстраждання, любов, тобто всі основоположні етичні характеристики спілкування. 
Важливо зазначити, що процес комунікації має велике значення для розвитку майбутніх офіцерів поліції, їхнього соціального самопочуття, успішної освітньої діяльності. Адже потреба в комунікації полягає у прагненні людини до пізнання і оцінці інших людей, а через них та 3 їхньою допомогою - до самопізнання, самооцінки [20].

Також, щоб краще зрозуміти поняття «комунікація» вважаємо за потрібне з'ясувати співвідношення понять «комунікація» та «спілкування», оскільки існують різні підходи до цього питання.

Спілкування «Великий тлумачний словник сучасної української мови» визначає це поняття як «взаємні стосунки та діловий, творчий зв'язок» [4, с. 133].

За визначенням психологічного словника, «спілкування» - це складний, багатоплановий процес, що встановлює контакти між людьми, який породжує необхідність у сучасній діяльності в містить в собі обмін інформацією, опрацювання єдиної стратегії взаємодії, сприйняття, і розуміння іншої людини У працях ряду авторів терміни «спілкування» і «комунікація» вживаються синонімічно, можливо це пов'язано з тим, що в іноземній літературі ці поняття не розділяються, а позначаються одним словом communication, проте, в багатьох публікаціях виявлені суттєві відмінності між цими поняттями [2, с. 87].

В теоретичній літературі існують різні точки розу на проблему спілкування.

М. Леонов показує класичну характеристику спілкування як форму діяльності, яка відбувається між людьми як рівними партнерами і призводить до виникнення психологічного контакту, що виникає внаслідок обміну інформацією, взаємовпливу, взаємохвилюванні та взаєморозумінні. Автор розрізняє наступні види спілкування: соціально-орієнтоване, групове предметно-орієнтоване, особистісно-орієнтоване [7, с. 56].

В. Панферов розуміє спілкування як механізм соціальної регуляції спільної життєдіяльності людей засобами інформаційно-комунікативної і психологічної взаємодії один з одним, а також зазначає, що існують дві загальні форми спілкування: опосередковане і безпосереднє, причому опосередкованим його може зробити людина або засіб зв'язку [9, с. 24].

К. Платонов розглядає спілкування як окремі випадки обміну інформацією і мають назву вони комунікації. Підтримує цю точку зору і Є. Ільїн, який визначає спілкування, як окремий вид комунікації. 
У його теорії говориться про те, що комунікація - це взаємодія (зв'язок) двох систем, у ході якої від однієї системи до іншої передається сигнал, що містить інформацію. Тобто комунікація це не лише людина-людина (тварина), а й взаємодія людина - машина, прилади. I лише перший вид, специфічних для високоорганізованих живих істот, належить до спілкування. За Є. Ільїним визначається, що у процесі спілкування відбувається не просто здобуття чи обмін інформації, але й емоційна взаємодія. Адже під час взаємодії людей виникає двопільний психічний контакт, який виявляється в передачі партнеру по спілкуванню інформації (вербальної, невербальної) і має за мету встановлення взаєморозуміння і взаємопереживання [6, с. 78].

В. Андрєєв у структурі спілкування виділяє комунікативний, інтерактивний, і перцептивний аспекти: комунікативне спілкування - це обмін інформацією між індивідами, інтерактивне спілкування - це обмін діями між індивідами, які спілкуються, а перцептивне спілкування - це процес сприйняття один одного партнерами по спілкуванню і встановлення на цій основі взаєморозуміння [8, с. 78].

Іншу точку зору ми знаходимо у О.О. Леонтьєва, який розуміє спілкування як один з видів діяльності. Він уточнює, що мається на увазі, що спілкування може бути як самостійна діяльність, так і бути лише компонентом, складовою частиною і одночасно умовою іншої некомунікативної діяльності [1].

Б. Ломов у своїй праці «Спілкування як проблема загальної психології» говорить, що: «поняття «спілкування» охоплює не діяльність, а іншу категорію реально існуючих стосунків «суб'єкт-суб'єкт» (тобто відбувається взаємодія суб'єктів, які виступають в якості партнерів). Хоча діяльність та спілкування мають багато спільних рис, цього ще не достатньо для їхнього ототожнення» [20].

Отже, за спільною думкою науковців, спілкування - це трьохкомпонентна структура, яка складається з когнітивного (це психологічне відображення учасниками спілкування один одного), поведінкового (це їх ставлення один до одного) і афективного компонента (має характер емоційного відгуку на ситуацію спілкування). Вперше цю думку висловив у 70-х роках минулого століття В. М'ясищєв на симпозіумі по проблемам спілкування, яка в подальшому знайшла своє відображення та розвиток у працях О. Бодальова [12, с. 56]. 
3 вищезазначеного можемо зробити висновок, що справжнє спілкування не потребує «відправника» та «одержувача» інформації, тому що йому необхідна спільність людей, тобто потрібні співрозмовники, співучасники спільної справи.

На нашу думку, щодо обговорення співвідношення цих понять сnілкування та комунікаиія має місце дещо штучне перебільшення їх розбіжностей. Тобто спільним у цих двох поняттях $є$ процес перетворення, сприйняття і поширення інформації як засіб персонального і масового впливу на економічному та соціальному рівні. Решта, це швидше наукова традиція вжитку, ніж остаточне розмежування понять.

У нашому дослідженні ми будемо вважати «комунікацію» більш ширшим поняттям ніж «спілкування». Тому що, з глобалізацією та інформатизацією сучасного світу ділова комунікація є складним та різноманітним процесом обміну важливою інформацією між учасниками спілкування. Ми підтримуємо точку зору О. Краєвської, яка вважає базовою категорією саме комунікацію, а спілкування розглядається лише як акт комунікації [3, с. 22].

Далі зупинимося на поясненні ще однієї категорії, яка має багато спільного з поняттям комунікативної компетентності.

На сьогодні поняття «комунікативна культура» ще остаточно не сформувалося, хоча різноманітні його аспекти були відображені в науково-педагогічних дослідженнях (Г. Андрєєва, О. Бодальов, І. Зимня, Б. Ломов, А. Мудрик, О. Леонтьев, І. Синиця, В. Грехнєв, В. Кан-Калик, С. Кондратьєва, інші). Такі вчені як Т. Ковіна, О. Колеченко, I. Агафонова трактують це поняття як вміння реалізувати на практиці особистісно-орієнтоване ставлення в ситуаціях професійної діяльності й вважають, що таке вміння притаманне педагогу. Взагалі, на думку дослідників, комунікативна культура $\epsilon$ проявом загальної культури людини, що виражена у системі потреб, соціальних якостей, стилю діяльності та поведінки людини. Вивчаючи джерельну базу, виявлено, що в наукових працях видатних учених П. Блонського, Л. Виготського, Я. Коменського, С. Русової, К. Ушинського, В. Сухомлинського, А. Макаренка, закладено теоретичні основи педагогічного спілкування та формування комунікативної культури педагога. Також теоретичний аналіз, дозволяє зробити висновок, що становлення дефініції «комунікативна культура» відбувалося на основі певної трансформації 
й переосмислення поняття «культура спілкування» як систему взаємодії, стосунків, контактів тощо, визначає його як цілісне суспільне й духовне, зокрема психологічне й моральне утворення. За змістовим наповненням це поняття наближається до комунікативної етики і забезпечує, насамперед, успішну адаптацію людини до соціального середовища [9, с. 54].

Аналіз думок дослідників потребує уточнення поняття «культура спілкування - це інтегроване вміння спілкуватися згідно з моральними нормами, які історично склалися у певному мовному колективі, із врахуванням психологічних механізмів впливу на адресата, використовуючи лінгвістичні засоби і способи реалізації такого спілкування 3 метою досягнення найбільш прагматичного ефекту [23, с. 43].

Отже, формування комунікативної компетентності майбутніх офіцерів поліції - це спеціально організований, цілеспрямований процес розвитку й активізації професійно необхідних комунікативних якостей, знань, вмінь та навичок, що обумовлюють успішне, ефективне, виконання функціональних повноважень, з вираженою комунікативною складовою [4, с. 37].

Також, згідно з концептуальними положеннями контекстного навчання А. Вербицького навчальна діяльність майбутніх офіцерів поліції повинна бути адекватною їх практичному застосуванню в професійній діяльності, тобто «щоб бути теоретично і практично компетентним, необхідно зробити подвійний підхід: від знака до думки, від думки до вчинку, дії. Перехід від інформації до ії використання опосередковується думкою, що і робить цю інформацію знанням» [6, с. 50]. Зокрема цьому допомагає вивчення такої дисциплін як «Особиста безпека працівників органів Національної поліції». Вивчення таких тем, як природні, техногенні, соціальні надзвичайні ситуації, надають майбутнім офіцерам поліції професійні знання під час занять з фахових дисциплін та комунікативні навички під час вивчення цих тем на заняттях 3 дисципліни «Тактико-спеціальна підготовка», «Цивільний захист».

Мета вивчення особистої безпеки полягає у тому, щоб сформувати у майбутніх офіцерів поліції свідоме й відповідальне ставлення як до питань особистої безпеки так і безпеки оточуючих, навчити їх розпізнавати й оцінювати потенційні небезпеки, визначати шлях надійного захисту від них, уміти в разі потреби надати допомогу собі та іншим, 
а також оперативно ліквідовувати наслідки прояву небезпек у різноманітних сферах людської діяльності.

На нашу думку, сутність процесу формування комунікативної компетентності майбутніх офіцерів поліції можна розглядати як підготовку до спілкування в різних умовах професійної діяльності. В іiі основі - рівноправна взаємодія суб'єктів цього процесу. Такий підхід передбачає комплексне використання сукупності засобів навчання під час вивчення дисципліни «Особиста безпека працівників органів Національної поліції», а також побудову цілісного освітнього процесу метою формування у майбутніх офіцерів поліції комунікативної компетентності. Одними з таких засобів можуть виступати мобільні ресурси.

\section{4. Загальне уявлення про мобільні ресурси}

Термін «мобільне навчання» (m-learning), що з'явився в англомовній літературі близько 10 років тому, останнім часом став все частіше використовуватися в нашій країні. Багато вчених і педагогів впевнені, що майбутнє навчання з підтримкою інформаційних технологій пов'язано і залежить саме від розповсюдження мобільних засобів зв'язку, популярності смартфонів і планшетів, появи великої кількості освітніх програм, а також нових технологій типу жестикуляційного інтерфейсу, який розширює можливості й якість освіти, здешевлення послуг мобільного зв'язку та бездротового доступу в Інтернет.

Проблемі формування інформаційного освітнього простору присвячено чимало досліджень у різних країнах світу (Україна, Білорусь, Німеччина, Польща, та ін.). Серед науковців, які опікуються цією проблемою, можна назвати В. Бикова, А. Гуржія, М. Жалдака, А. Литвина, Н. Морзе, В. Олійника, О. Співаковського, Ю. Триуса, Гж. Кєдровича, В. Бикова, М. Жалдака, І. Богданової, І. Теплицького, Е. Сарафанюка, О. Кузнєцова, В. Монахова, Е. Полат, І. Роберт тощо.

Теоретичні й практичні аспекти використання інтерактивних методів навчання відображено у доробках І. Вачкова, Ю. Смельянова, С. Крамаренко, А. Мартинець, Н. Оганесян, Л. Пироженко, О. Пометун, Т. Яценко.

Б. Банністер стверджує, що розвиток мобільних мультимедійних послуг, мобільного Інтернету, широкомовної мобільного зв'язку 
сприяє мобільному навчання. У науковій сфері обговорюються перспективи мобільні ресурси, визначаються компоненти гнучкого навчання, під яким розуміється дистанційне навчання - on-line, мобільне і дистанційне навчання.

Деякі вчені досліджують перспективи і можливості мобільного навчання. Так, А. Андрєєв, В. Солдаткін [8, с. 792] розглядають можливості використання портативних персональних комп'ютерів в дистанційному навчанні, вказують на відмінності між спеціалізованими (інтегральними навчальними системами, текстовими плеєрами, калькуляторами, електронними блокнотами) і універсальними пристроями, мережевими і немережевими.

I. Безкровний [2, с. 25-31] вказує на те, що в основі впровадження мобільних ресурсів лежить уявлення про те, що даний процес перебуває у відповідності з сучасним етапом розвитку суспільства, в тому числі і економічним. У 1990-ті роки навчання характеризується як проблемно-сфокусоване. На сучасному етапі в західній науці йдеться про контекстуальному, неформальному і безперервному навчанні. В якості основних характеристик сучасного навчання вказуються оріснтованість на учня, індивідуальний підхід, коллаборативність, ситуаційність, безперервність, доступність. Нові технології відрізняються орієнтованістю на учня, індивідуалізованістю, мобільністю і доступністю.

А. Федосєєв, А. Тимофєєв, говорячи про мобільні технології в освіті, вказують, що сучасні комунікаційні пристрої створюють умови для мобільної роботи в різних професійних сферах - науці, бізнесі та освіті. Автори відзначають перспективність використання сучасних мобільних пристроїв в процесі дистанційного навчання. Незважаючи на те, що використання деяких мобільних засобів для вивчення навчального матеріалу ускладнюється через невеликих розмірів екрану, можливе застосування спеціальних пристроїв виведення інформації, наприклад, очок, що дозволяють досягти високого дозволу. За допомогою мобільних пристроїв учасники навчального процесу взаємодіють один з одним. При цьому ступінь інтерактивності і управління навчальним процесом різні.

Необхідність модернізації як відомчої системи професійної підготовки, так і всієї вітчизняної освітньої системи в цілому, відображає загальнонаціональні інтереси у сфері освіти й грунтується на загаль- 
них тенденціях світового розвитку, які обумовлюють перехід до інформаційного суспільства i, як наслідок цього - необхідність суттєвих змін у системі освіти в умовах глобальної інформатизації. Вирішення цих питань $є$ одним з визначальних умов розвитку вітчизняної освіти, що знайшло своє відображення в цілому ряді державних документів України, зокрема, в Національній стратегії розвитку освіти в Україні на 2012-2021 роки наголошується на тому, що одним з першочергових кроків розвитку освіти і науки є їхня інформатизація, тобто «впровадження сучасних інформаційно-комунікаційних технологій, що забезпечують удосконалення навчально-виховного процесу, доступність та ефективність освіти, підготовку молодого покоління до життєдіяльності в інформаційному суспільстві» [1, с. 143].

Сучасні мобільні ресурси передбачають реалізацію інформаційних та комунікаційних процесів, а саме: методів пошуку, збору, обробки, розповсюдження інформації та процесів й методів поширення отриманої інформації.

Вагомими для майбутнього офіцера є якості, що необхідні для неперервного професійного розвитку протягом усієї кар'єри. Саме сучасними засобами мобільних ресурсів формуються компетентності, які визначають здатність майбутнього офіцера поліції до самоосвіти. Зокрема, необхідно відзначити аспект самоуправління власною освітньою діяльністю. 3 цього випливає, по-перше, що мобільні ресурси через свої широкі можливості створюють умови для задоволення освітніх потреб здобувача вищої освіти, а, отже, виконують мотиваційну функцію. По-друге, за допомогою мобільних ресурсів майбутній офіцер набуває здатності до самоорганізації самостійної освітньої діяльності. Таким чином майбутній офіцер поліції оволодіває відповідними уміннями та такими якостями, як само дисциплінованість, відповідальність перед собою, пунктуальність, організованість тощо. По-третє, мобільні ресурси допомагають удосконалювати майбутньому офіцеру поліції такі уміння як опрацювання текстів, відео- та аудіоматеріалів, виконання творчих робіт, роботу з електронними ресурсами тощо. По-четверте, мобільні ресурси допомагають оцінити сформованість тих чи інших професійних компетентностей, що дозволяє реалізувати контрольну функцію та визначати актуальні цілі фахового розвитку близької та далекої перспективи. 
Отже, існує декілька трактувань і визначень мобільного навчання, що грунтуються або на технологічних особливостях мобільних пристроїв, або на дидактичних можливостях, які надаються цими технологіями [1, с. 20].

\section{5. Мобільні ресурси в освітньому процесі}

3 технологічної точки зору, мобільне навчання - це передача і отримання навчальної інформації з використанням технологій WAP або GPRS на будь-який портативний мобільний пристрій, за допомогою якого можна вийти в Інтернет, отримати чи знайти матеріали, відповісти на запитання на форумі, виконати тест тощо. Для мобільного навчання можуть використовуватися такі типи мобільних пристроїв: мобільні засоби зв'язку - мобільні телефони, смартфони, комунікатори; різні портативні мобільні пристрої - MP3/4 плеєри, електронні книги, пристрої для електронних ігор, пристрої для прослуховування подкастів, навігатори, цифрові фотоапарати і відеокамери тощо; портативні комп'ютери - портативний кишеньковий комп'ютер, планшетний комп'ютер, нетбуки, ультрабуки тощо [7, с. 143].

Вважається, що мобільне навчання змінює повністю процес навчання, оскільки мобільні пристрої модифікують не тільки форми подачі матеріалу і доступу до нього, а й сприяють створенню нових форм пізнання і менталітету. Навчання стає своєчасним, достатнім і персоналізованим («just-in-time, justenoughand just-for-me»). Дані характеристики мобільного навчання контрастують 3 характеристиками змішаного і електронного навчання («e-learning»), в яких на перше місце виходять такі дидактичні принципи як мультимедійність, структурованість чи модульність, інтерактивність, доступність. Мобільні технології трансформують баланс між процесом навчання та участю курсанта/ студента. Саме тому мобільне навчання - це нова форма навчання, що відрізняється від дистанційного чи змішаного, що характеризує новий виток розвитку інформатизації людського суспільства [4, с. 193].

Сьогодні, мабуть, важко знайти людину, яка б не знала про мобільні телефони, можливості їхнього використання у повсякденному житті, але й важко нині знайти інформацію про негативні сторони стільникового, мобільного зв'язку.

Стільниковий телефон - мобільний телекомунікаційний пристрій, який використовує комбінацію радіопередачі та традиційну телефонну комута- 
цію з метою здійснення телефонного спілкування на території, котра складається із «стільників» навколо базової станції стільникової мережі. Базова станція також займається аутентифікацією викликів [4, с. 233].

Виділимо функціональні можливості стільникового або мобільного зв'язку, що використовуються в навчанні: голосовий зв'язок; sms (shoht Message Service) - обмін коротенькими повідомленнями; mms (Multimedia Messaging Service) дозволяє добавляти у повідомлення звук і зображення; Instant Massager - система обміну життєвими повідомленнями; модем і доступ в Інтернет; WAP-браузер; зв'язок із комп'ютером або іншим пристроєм за допомогою кабелю інфрачервоного порту або Bluetooth; засоби роботи з електронною поштою; підтримка змінних карт флеш - пам'яті; календар; секундомір; підтримка Jawa; MP 3 - плеєр; диктофон; цифровий фотоапарат, цифрова відеокамера.

Зупинимося на деяких прикладах використання сервісів мобільного зв'язку: введення SMS - щоденників, дає можливість батькам отримувати інформацію успішності їхньої дитини з електронного журналу навчального закладу; SMS - референдуми з актуальних питань; SMS перекладачі, довідники, (ця послуга досить вартісна для пересічних громадян); дистанційне листування, консультування. Розглядаючи не голосове спілкування, слід зазначити важливість якісної вбудованої програми та іiі сервісу (Лапінський). Відзначимо програми: Colibry та Mailman. (Colibry для спілкування в мережі Jabber; Mailman - поштовий клієнт.) Mobispine - програма для спілкування, створює власні спільноти; Mobicg та Jimm (мобільні ICQ) клієнти.Широкі можливості для використання глобальної мережі Інтернет відкриває підключення мобільних телефонів до неї у різних варіаціях (Інтернет, I-mode, WAP - Інтернет) [10, с. 82].

Можливість безпосереднього виходу в Інтернет за допомогою мобільного телефону або використання його як модему, що приєднаний до персонального комп'ютера, ноутбука, нетбука, кишенькового комп'ютера, або іншого пристрою за допомогою дротового або бездротового зв'язку розширює можливості інформатизації освіти, розвитку інформаційної культури [11, с. 174].

Враховуючи той факт, що кількість мобільних телефонів і комунікаторів приблизно втричі більша, ніж кількість персональнихкомп'юте- 
рів, не використати такий потенціал мобільних технологій в навчанні неможливо [1, с. 67].

Зазначимо також, що ряд авторів підкреслюють відмінність між мобільним навчанням і так званим «е-learning», кажучи, що унікальність мобільного навчання полягає в тому, що здобувачі вищої освіти перш за все не прив'язані до певного часу і місця, навчальний матеріал завжди під рукою, вивчається в будь-який час, тому такий розвиток подій дозволяє їм звикнути до думки, що вчитися потрібно і можна завжди, в будь-який зручний час. Таким чином, беззаперечними перевагами використання мобільних пристроїв і технологій $\epsilon$ [8, с. 156]: швидкий доступ до навчальних і довідникових ресурсів і програм в будь-який час і в будь-якому місці; постійний зворотний зв'язок 3 викладачем і навчальним співтовариством; облік індивідуальних особливостей здобувачів вищої освіти - діагностика проблем, індивідуальний тематичний план навчання тощо; підвищення мотивації здобувачів вищої освіти за рахунок використання знайомих технічних засобів і віртуального оточення; організація автономного навчання; створення персоналізованого професійно оріснтованого навчального простору здобувачів вищої освіти; розвиток навичок і здібностей до безперервного навчання протягом життя; підвищення кваліфікації викладачів без відриву від роботи.

Отже, ми вважаємо, що використання мобільних ресурсів під час професійної підготовки майбутніх офіцерів поліції, а саме на семінарських та практичних заняттях 3 дисципліни «Основи охорони праці», буде сприяти вирішенню таких дидактичних завдань: розвиток комунікативних умінь; розвиток умінь самостійної роботи; розвиток здібностей до соціальної взаємодії; стимулювання пізнавальної активності й мотивації до подальшого вивчення комунікації тактики дій.

Як бачимо суттєве значення у процесі самоосвіти відводиться сучасним технологіям освіти, педагогічній спрямованості змісту навчального матеріалу, а також умовам для засвоєння нових знань, тобто, мова йде не лише про відбір змісту навчального матеріалу, а й про інтерактивне інформаційне середовище. Також важливим є мотиваційне та технологічне забезпечення самостійної аудиторної та позааудиторної роботи здобувачів вищої освіти. 
Вважаємо, що мобільні ресурси доцільно використовувати для підтримки навчання за моделлю змішаного навчання, за якого традиційні технології поєднуються з інноваційними технологіями дистанційного, електронного та мобільного навчання задля створення гармонійного поєднання теоретичного та практичного складників процесу навчання, оскільки надають здобувачам вищої освіти можливість вдосконалювати свої комунікативні уміння, формують навички електронної комунікації.

Загально відомо, що оволодіння комунікативними та інформативними компетентностями є невід'ємною частиною життя більшості людей. Це дозволяє майбутньому фахівцеві бути успішним у сучасному інформаційному суспільстві, приймати та реалізовувати оптимальні рішення в сфері професійно-комунікативної діяльності; віддзеркалює його здатність до визначення інформаційної потреби, пошуку інформації як традиційним способом, так і за допомогою мобільних ресурсів [12, с. 98].

Мобільні ресурси дозволять підготуватися майбутнім офіцерам поліції до активної взаємодії та комунікації у професійній сфері, а також допомагатимуть у самостійній навчальній діяльності.

Особливого значення при індивідуалізації навчання набуває контроль якості знань, та навичок здобувачів вищої освіти, який має бути систематичним, постійний персональним. Здійснювати такий контроль, як правило не легко. Використання технічних засобів контролю, так званих програм контролю, значно полегшує роботу викладача. Застосування на заняттям мобільних ресурсів при виконанні тестів дозволяє за короткий час отримати об'єктивну картину рівня засвоєння навчального матеріалу у всіх здобувачів вищої освіти і своєчасно його скорегувати. Для здобувача вищої освіти важливо відразу після закінчення самостійної роботи отримати об'єктивний результат із зазначенням помилок. Мобільний додаток Plickers дозволяє проводити миттєве фронтальне опитування: кожен здобувач вищої освіти дає відповідь на запитання за допомогою індивідуального QR-коду, викладач сканує одночасно всі відповіді, використовуючи смартфон, і результати тесту виводяться на екран образу після завершення тестування. Такі тести більш цікаві для здобувачів вищої освіти, ніж традиційні форми контролю.

Вважаємо, що для викладачів, які виявляють бажання вдосконалити вміння користуватися мобільними ресурсами, у вищих навчаль- 
них закладах варто якнайчастіше організовувати відповідні семінари та майстер-класи й залучати до цього процесу компетентних фахівців.

Отже, можливості використання мобільних ресурсів величезні, оскільки вони створюють умови для отримання необхідної інформації здобувачами вищої освіти, що знаходяться поза аудиторією. Перед тими, хто навчається, відкривається можливість самостійно планувати, здійснювати навчання за окремим графіком, будь-коли одержати доступ до навчальних матеріалів, можливість одержання необхідної консультації, відповіді на поточні запитання.

\section{6. Висновки}

Очевидним постає, що в сучасних умовах викладання у вищому навчальному закладі не можна обмежуватися тільки традиційними формами і методами. Необхідним і закономірним $є$ використання мобільних ресурсів, за допомогою яких відбувається модернізація форм проведення занять, що є важливою складовою при формуванні комунікативної компетентності, тому що вони відкривають доступ до нових джерел інформації, активізують процеси соціокультурних в'язків, надають нові можливості для формування професійних навичок. Окремо варто зазначити, що є можливість забезпечити зворотній зв'язок зі здобувачами вищої освіти безперервно за допомогою мобільних ресурсів. Але у даному випадку практика застосування мобільних ресурсів розглядалася нами не лише з позиції ефективного зворотного зв’язку, але і у якості складової опанування дисципліни «Особиста безпека працівників органів внутрішніх справ», що, в свою чергу, забезпечує комунікативність, продуктивність та економічність освітнього процесу. Окрім цього, вирішується основне завдання нових педагогічних технологій - збільшення часу спілкування із здобувачами вищої освіти в аудиторії. Іншими словами, мобільні ресурси дають можливість швидкого доступу до інформації, постійно підвищувати власну кваліфікацію, якість виконання робіт, підтримувати професійну працездатність.

Перспективи подальших наукових розвідок ми пов'язуємо із розширенням наукових уявлень щодо впровадження мобільних ресурсів у зміст професійно орієнтованих дисциплін у процесі формування комунікативної компетентності майбутніх офіцерів поліції. 


\section{Список літератури:}

1. Биков В.Ю. Мобільний простір і мобільно-орієнтоване середовище інтернет-користувача: особливості модельного подання та освітнього застосування. Інформаційні технології в освіті. 2013. № 17. С.9-37.

2. Гульчевская В.Г., Гульчевская Н.Е. Современные педагогические технологии. Ростов-на-Дону : Издательство-РИПК и ПРО, 1999. 346 с.

3. Коневщинська О.Е. Електронні освітні ресурси у межах інформаційного забезпечення ресурсного центру дистанційного навчання. Інформаційні технології $і$ засоби навчання. 2014. № 5(43). С. 164-173.

4. Коневщинська О.Е. Кадрове забезпечення ресурсного центру дистанційного навчання. Інформаційні технологіï $i$ засоби навчання. 2013. № 6(38). С. 182-195.

5. Коневщинська О.Е. Новітні технології у роботі ресурсного центру дистанційної освіти. URL: http://lib.iitta.gov.ua/IITZN-2014.pdf\#page=32 (дата звернення: 06.04.2018).

6. Коневщинська О.Е. Формування ІКТ-компетентності викладачів-тьюторів ресурсних центрів дистанційної освіти. Інформаційні технологї $i$ засоби навчання. 2014. № 4(42). С. 20-32.

7. Купчигина И.М. Изучение коммуникативной компетентности студентов первых и четвертых курсов, обучающихся по педагогическим направлениям. Личность, семья и общество: вопросы педагогики и психологии: сборник статей по результатам ХХХVII международной научно-практической конференции. Новосибирск : СибАК, 2014. № 2(37).

8. Лапінський В.В. Електронні освітні ресурси - дидактичні вимоги класифікація. Педагогічний дискурс. 2010. № 7. С. 142-148.

9. Литвинова С.Г. Критерії оцінювання локальних електронних освітніх ресурсів. Інформаційні технологї в освіті. 2013. № 15. С. 185-192.

10. Мильруд Р.П., Максимова И.Р. Современные концептуальне принципы коммуникативного обучения иностранному языку. Иностранные языки в школе. 2000. № 4. С. 9-16.

11. Подласый И.П. Педагогика: 100 вопросов - 100 ответов. Москва : ВЛАДОС-пресс, 2006. 365 с.

12. Седов К.Ф. Онтопсихолингвистика: становление коммуникативной компетенции человека. Москва : Лабиринт, 2008. 320 с.

13. Хуторской А.В. Компетентностный подход в обучении. Москва : Эйдос, 2013. 73 с.

14. Михайлова (Алешина) Е.С. Тест Дж. Гилфорда и М. Салливена. Диагностика социального интеллекта. Руководство пользователя. СанктПетербург : ГП «Иматов», 2001. 51 с.

16. Бойко В.В. Энергия эмоций. Санкт-Петербург : Питер, 2004. 474 с.

17. Рогов Е. И. Настольная книга практического психолога: В 2 кн. Москва : ВЛАДОС, 1999.Кн.2:Работапсихолога со взрослыми. Коррекционные приемы и упражнения. $480 \mathrm{c}$.

18. Про затвердження Положення про електронні освітні ресурси : Наказ Міністерства освіти і науки, молоді та спорту України № 1060 від 01.10.2012 р. URL: http://zakon.rada.gov.ua/laws/show/z16 (дата звернення: 06.04.2018). 
19. Сучасні інформаційні технології та інноваційні методики навчання у підготовці фахівців: методологія, теорія, досвід, проблеми : Збірник наукових праць. 2007. Випуск 15.492 с.

20. Bulvinska O. Teacher communication competence: different theoretical approaches. Internauka. 2017. № 15(37). Vol. 1. P. 20-23. DOI: https://doi.org/ $10.25313 / 2520-2057-2017-15$

\section{References:}

1. Bykov V.Yu. (2013). Mobilnyi prostir i mobilno-oriyentovaneseredovyshche internet-korystuvacha: osoblyvosti modelnoho podannia ta osvitnioho zastosuvannia [Mobile space and mobile-oriented environment of the Internet user: the peculiarities of model presentation and educational application]. Informatsiini tekhnolohii v osviti, 17, 9-37. (in Ukrainian)

2. Gulchevskaya V.G., Gulchevskaya N.E.(1999). Sovremennye pedagogicheskie tehnologii [Modern educational technology]. Rostov-na-Donu: Izdatelstvo-RIPK i PRO. (in Russian)

3. Konevshchynska O.E. (2014). Elektronni osvitni resursy u mezhakh informatsiinohoz abezpechennia resursnoho tsentru dystantsiinoho navchannia [Electronic educational resources within the information support of the resource center of distance learning]. Informatsiini tekhnolohii i zasoby navchannia, 5(43), 164-173. (in Ukrainian)

4. Konevshchynska O.E. (2013). Kadrove zabezpechennia resursnoho tsentru dystantsiinoho navchannia [Personnel provision of a resource center for distance learning]. Informatsiini tekhnolohii i zasoby navchannia, 6(38), 182-195. (in Ukrainian)

5. Konevshchynska O.E. (2014). Novitni tekhnolohii u roboti resursnoho tsentru dystantsiinoi osvity [Modern technologies in the resource center of distance education]. Informatsiini tekhnolohii i zasoby navchannia, 5 (43), 23-30. (in Ukrainian)

6. Konevshchynska O.E. (2014). Formuvannia IKT-kompetentnosti vykladachivtiutoriv resursnykh tsentriv dystantsiinoi osvity [Formation of ICT-competence of teachers-tutors of resource centers of distance education]. Informatsiini tekhnolohii $i$ zasoby navchannia, 4(42), 20-32. (in Ukrainian)

7. Kupchigina I.M. (2014). Izuchenie kommunikativnoj kompetentnosti studentov pervyh i chetvertyh kursov, obuchayushihsya po pedagogicheskim napravleniyam [The study of the communicative competence of first and fourth year students enrolled in pedagogical areas]. Lichnost, semya i obshestvo: voprosy pedagogiki i psihologii: sbornik statej po rezultatam XXXVII mezhdunarodnoj nauchno prakticheskoj konferencii. Novosibirsk: SibAK, 2(37).

8. Lapinskyi V.V. (2010). Elektronni osvitnir esursy - dydaktychni vymohy klasyfikatsiia [Electronic educational resources - didactic requirements and classification]. Pedahohichnyi dyskurs, 7, 142-148. (in Ukrainian)

9. Lytvynova S.H. (2013). Kryterii otsiniuvannia lokalnykh elektronnykh resursiv [Criteria for assessing local e-learning resources]. Infromatsiini tekhnolohii v osviti, 15, 185-192. (in Ukrainian) 
10. Milrud R.P., Maksimova I.R. (2000). Sovremennye konceptualnye principy kommunikativnogo obucheniya inostrannomu yazyku [Modern conceptual principles of communicative teaching of a foreign language]. Inostrannye yazyki $v$ shkole, $4,16$.

11. Podlasyj I.P. (2006). Pedagogika: 100 voprosov-100 otvetov [Pedagogy: 100 questions -100 answers]. Moskow: VLADOS-press. (in Russian)

12. Sedov K.F. (2008). Ontopsiholingvistika: stanovlenie kommunikativnoj kompetencii cheloveka [Ontopsycholinguistics: the formation of human communicative competence]. Moskow: Labirint. (in Russian)

13. Hutorskoj A.V. (2013). Kompetentnostnyj podhod v obuchenii [Competence approach to learning]. Moskow: Ejdos. (in Russian)

14. Mihajlova (Aleshina), E.S. (2001). Test Dzh. Gilforda i M. Sallivena. Diagnostika socialnogo intellekta. Rukovodstvo polzovatelya [Test J. Guilford and M. Sullivan. Diagnosis of social intelligence. User's manual]. Saint Petersburg: GP «Imatov». (in Russian)

15. Bojko V.V. (2004). Energiya emocij [The energy of emotions]. Saint Petersburg: Piter. (in Russian)

16. Rogov E.I. Nastolnaya kniga prakticheskogo psihologa: V $2 \mathrm{kn}$. [Handbook of practical psychologist: In 2 books]. Moskow: VLADOS, 1999. Kn. 2: Rabota psihologa so vzroslymi. Korrekcionnye priemy i uprazhneniya. (in Russian)

17. Pro zatverdzhennia Polozhennia pro elektronni osvitni resursy : Nakaz Ministerstva osvity i nauky, molodi ta sportu Ukrainy № 1060 vid 01.10.2012 r. [On approval of the regulations on electronic educational resources: Order of the Ministry of Education and Science, Youth and Sports of Ukraine No. 1060 dated October 1, 2012]. Retrieved from: http://zakon.rada.gov.ua/laws/show/z16 (in Ukrainian)

18. Suchasni informatsiini tekhnolohii ta innovatsiini metodyky navchannia $u$ pidhotovtsi fakhivtsiv: metodolohiia, teoriia, dosvid, problemy: Zbirnyk naukovykh prats [Modern information technologies and innovative methods of training in the training of specialists: methodology, theory, experience, problems: collection of scientific works] (2007), 15. (in Ukrainian)

19. Bulvinska O. (2017). Teacher communication competence: different theoretical approaches. Internauka, no. 15(37), vol. 1, pp.20-23. DOI: https://doi.org/ $10.25313 / 2520-2057-2017-15$ 